\title{
CORRELATION: IMPEDANCE AND TOMOGRAPHY IN IMPLANTS INSERTION IN LUMBAR ARTHRODESIS
}

\author{
CORRELAÇÃO: IMPEDÂNCIA E TOMOGRAFIA NA INSERÇÃO DE IMPLANTES \\ EM ARTRODESE LOMBAR
}

\section{CORRELACIÓN: IMPEDANCIA Y TOMOGRAFÍA EN LA INSERCIÓN DE IMPLANTES EN ARTRODESIS LUMBAR}

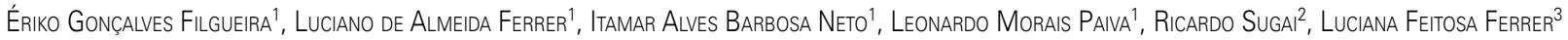

1. Hospital de Base do Distrito Federal, Orthopedics and Traumatology Service, Brasília, DF, Brazil.

2. Hospital de Base do Distrito Federal, Anesthesiology Service, Brasília, DF, Brazil.

3. Hospital Ortopédico, Spine Service, Belo Horizonte, MG, Brazil.

\begin{abstract}
Objective: To define whether the electroneurophysiological stimulation would be a safe method for reducing injuries in nerve roots during surgery of lumbar spine arthrodesis, as well as verify whether there is a direct correlation between the intraoperative impedance values and the distance from the medial cortical pedicle screw. Methods: Randomized retrospective multicenter study of 10 patients who underwent arthrodesis of lumbar spine after conservative treatment failure, with a total of 50 pedicle screws instrumented. Reliable and safe impedance values were measured in order to reduce the risk of injury to nerve roots in the perioperative period, and these values were compared with the distance between the screw and the medial cortical of the pedicle by CT scan, measured in the immediate post-operative period. Results: There is no direct correlation between the intraoperative impedance values and the distance from the screw to the medial cortical of the pedicle. Conclusion: The electroneurostimulation proved to be a reliable quantitative method to reduce the risk of injury to nerve roots during surgery of lumbar spine arthrodesis when the measured values are greater than $10 \mathrm{~mA}$.
\end{abstract}

Keywords: Arthrodesis; Electric impedance; Spinal nerve roots; Electric stimulation.

\section{RESUMO}

Objetivo: Definir se a estimulação eletroneurofisiológica seria um método seguro para redução de lesões em raízes nervosas no intraoperatório de artrodese de coluna lombar, bem como verificar se há correlação direta entre os valores de impedância transoperatória e a distância do parafuso e a cortical medial do pedículo. Métodos: Estudo retrospectivo, multicêntrico com seleção randômica consecutiva de 10 pacientes que realizaram artrodese de coluna lombossacra após falha de tratamento conservador, com um total de 50 parafusos pediculares instrumentados. Os valores confiáveis e seguros de impedância para diminuir os riscos de lesão em raízes nervosas foram aferidos no período perioperatório, sendo esses valores comparados com os da distância entre o parafuso e a cortical medial do pedículo na tomografia computadorizada, aferida no pós-operatório imediato. Resultados: Não há correlação direta entre os valores de impedância transoperatória e a distância do parafuso até a cortical medial do pedículo. Conclusão: A eletroneuroestimulação mostrou ser um método quantitativo seguro para diminuir os riscos de lesões em raízes nervosas no intraoperatório de artrodese de coluna lombar quando os valores aferidos são maiores que $10 \mathrm{~mA}$.

Descritores: Artrodese; Impedância elétrica; Raízes nervosas espinhais; Estimulação elétrica.

\section{RESUMEN}

Objetivo: Definir si la estimulación electroneurofisiológica sería un método seguro para reducir las lesiones en las raíces nerviosas durante la cirugía de artrodesis de columna lumbar, así como verificar si hay correlación directa entre los valores de impedancia perioperatoria y la distancia entre tornillo y la cortical medial del pedículo. Métodos: Estudio retrospectivo, multicéntrico, con selección aleatoria consecutiva de 10 pacientes que fueron sometidos a la artrodesis de columna lumbosacra después de falla del tratamiento conservador, con un total de 50 tornillos pediculares instrumentados. Valores fiables y seguros de impedancia para reducir el riesgo de lesiones a las raíces nerviosas se midieron en el periodo perioperatorio, y estos valores se compararon con la distancia entre el tornillo y la cortical medial del pedículo en la tomografía computarizada, medida en el período postoperatorio inmediato. Resultados: No existe una correlación directa entre los valores de impedancia perioperatoria y la distancia desde el tornillo hasta la cortical medial del pedículo. Conclusión: La electroneuroestimulación mostró ser un método cuantitativo fiable para reducir el riesgo de lesiones a raíces nerviosas durante la cirugía de artrodesis de columna lumbar cuando los valores medidos son mayores que $10 \mathrm{~mA}$.

Descriptores: Artrodesis; Impedancia eléctrica; Raíces nerviosas espinales; Estimulación eléctrica. 


\section{INTRODUCTION}

The use of pedicle screws in lumbar segment arthrodesis is widely established in the surgical community. ${ }^{1}$ Third-generation instrumentation was first used by Cotrel and Dubousset in 1985, in Avanzi et al. ${ }^{2}$ This allowed for great mechanical stability as compared to other older systems, eliminating the need for external immobilization during the postoperative period. ${ }^{3,4}$ However, this technique depends on the accuracy of the surgeons performing the procedure, ${ }^{1}$ because the malpositioning of the implants is directly and indirectly associated with serious complications such as infections, pneumothorax, lesions of the dura mater, fractures of the pedicle, paraparesis, and loosening of the implant. ${ }^{5}$ According to Ravi et al., ${ }^{6}$ the incidence of malpositioned screws in the lumbar segment is $23 \%, 14$ to $30 \%$ being medial and 60 to $68 \%$ being lateral violations.,

Several methods are being used to accurately guide and confirm the positioning of pedicle screws, ${ }^{8-11}$ such as fluoroscopy, but they are not sufficient to predict screw violation with confidence. ${ }^{12-14}$ Computed tomography is significantly more sensitive and accurate in evaluating the positioning of pedicle screws, ${ }^{4}$ but feasible in most centers only in the immediate postoperative. The use of electrical stimulation of the pedicle screws to evaluate their correct positioning was developed by Calancie et al. ${ }^{15}$ initially in an animal model.

This method involves the electrical stimulation of the pedicle screws and the pedicle itself, using constant current pulses that cause an evoked potential in the myotomes corresponding to the nerve roots that are being stimulated. ${ }^{16}$ There is no evidence in bibliographical reviews of any value that determines pedicular integrity.

The objective of this study was to determine whether electroneurophysiological stimulation is a safe method for reducing the risk of intraoperative lesions of the nerve roots during spine arthrodesis and also to determine whether there is a correlation between the values of transoperative impedance measured at the head of the screw and the distance of the implant to the medial cortical of the pedicle using computed tomography in the immediate postoperative period.

\section{METHOD}

Ten consecutive patients were selected randomly, without previous calculation, who had undergone posterior approach instrumentation with pedicle screws in one or two levels from November, 2013, to June, 2014, in a multicenter, retrospective study, with a total of 50 pedicle screws implemented. All the patients were operated by the same team, consisting of four orthopedists and an electrophysiologist. Two doctors were positioned on each side of the patient, randomly determined at the beginning of the study and were not changed for any of the surgeries.

These data were later plotted in order to identify possible correlations between the distance from the medial cortical wall of the pedicle and the transoperative impedance.

Four male and six female patients participated in the study. The inclusion criteria were patients with degenerative pathologies of the lumbosacral spine who had undergone surgery following the failure of conservative treatment. The exclusion criteria were patients with spondylolisthesis, scoliosis, or any other pathologies that present anatomic pedicular changes or those who did not wish to participate in any phase of the study.

The implant technique used was that described by Kim et al. ${ }^{5}$ and $\mathrm{Li}$ et al. ${ }^{17}$ The entry point of the screw in the pedicle was the intersection between the line that passes in the mid-horizontal portion of the transverse process and the vertical line from the junction between the mid and lateral thirds of the upper articular process. ${ }^{18}$

The size of the implants varied in accordance with the preoperative patient exams. Monoaxial and polyaxial titanium pedicle screws of from 5.5 to $6.5 \mathrm{~mm}$ in diameter and of a length determined intraoperatively were used. ${ }^{1}$ During the surgical procedure, the neurophysiologist evaluated the impedance of the head of the screw instrumented in the pedicle through neurophysiological stimulation using the Viasys Endeavor apparatus, in addition to which the screws were observed using a GE Everview 7500 (www.ge.com/br) image intensifier in two orthogonal incidences.

Routine computed tomographies were obtained in the immediate postoperative, prior to hospital discharge, in dorsal decubitus using the GE LightSpeed Plus (www.ge.com/br) apparatus with parallel $2 \mathrm{~mm}$ sections of the pedicles in the sagittal, axial, and coronal planes. We sought to analyze the positioning of the pedicle screws for the presence of cortical pedicular lesions caused by the them. In a positive case, we quantified in millimeters the invasion of the pedicular cortical by the screw. Three parameters were considered in the measurement of any violation of the cortical bone of the pedicle: none, up to $2 \mathrm{~mm}$, and greater than $2 \mathrm{~mm}$, according to Xu et al. ${ }^{11}$ and Polly et al. ${ }^{19}$

Postoperative neurological exams were performed by the team in all the patients selected for the study and any neurological lesions different from those noted at patient admission were considered to be new.

The statistical evaluation was performed using $R$ software. We used the Shapiro-Wilk, Wilcoxon, Student's t, and Levene tests to confirm the existence of association between the variables. All the tests were applied with a significance level of $5 \%$.

This study was approved by the Institutional Review Board on the Plataforma Brasil (CAAE: 30463714.0.1001.5553).

\section{RESULTS}

Posterior approach arthrodesis was performed in 10 patients with degenerative pathology in lumbosacral follow-up who had failed conservative treatment. A total of 50 pedicle screws were positioned from L1 to S1 in one or two levels.

The tomographic evaluation verified that there was no violation of the pedicular cortical in any of the cases. The pedicle lesions were considered acceptable with up to $2 \mathrm{~mm}$ of impingement of the screw and unacceptable when greater than $2 \mathrm{~mm}$.

There was no significant difference between the average electrical current of the screws instrumented by the surgeons in terms of their position in the surgical field (on the right or on the left), as shown in Table 1.

There was no significant difference observed in the distance of the screws from the cortical wall of the pedicle viewed in computed tomography in the immediate postoperative period related to the position of the surgeons as shown in Table 2.

The lowest value of the electrical current measured was greater than $10 \mathrm{~mA}$ as shown in Figure 1, and the ratio of this amperage measurement to the distance of the pedicle screw from the medial cortical was less than 2, revealing that in the study in question the value of $10 \mathrm{~mA}$ was safe. However, there was no significant relationship between the electrical current measured and the distance between the screws and the medial cortical of the pedicle, as shown in Figure1 and Table 3.

\section{DISCUSSION}

The potential morbidity associated with anterior access lumbar fusions is known, ${ }^{20}$ which made it one of the factors that influenced

Table 1. Proof of the non-statistical significance of the impedance measured in terms of the position of the surgeons using the t test.

\begin{tabular}{c|c|c|c|c|c|c}
\hline \multicolumn{2}{|c|}{} & \multicolumn{3}{|c|}{$\begin{array}{c}\text { Levene test for } \\
\text { equality of variances }\end{array}$} & \multicolumn{3}{|c}{$\begin{array}{c}\text { T test for the equality } \\
\text { of averages }\end{array}$} \\
\cline { 3 - 7 } \multicolumn{2}{c|}{} & F & Sig. & t & d.f. & p-value \\
\hline $\begin{array}{c}\text { Electrical } \\
\text { current }\end{array}$ & $\begin{array}{c}\text { Variances } \\
\text { assumed to be } \\
\text { equal }\end{array}$ & 0.244 & 0.6236 & -1.0834 & 48 & 0.2841 \\
\hline
\end{tabular}

Table 2. Distance in mm between the screw and the medial cortex of the pedicle in terms of the position of the surgeon.

\begin{tabular}{c|c|c|c}
\hline \multirow{2}{*}{} & \multicolumn{3}{|c}{ Wilcoxon test for the equality of averages } \\
\cline { 2 - 4 } & $\mathbf{W}$ & d.f. & p-value \\
\hline Average distance of the screw & 308.5 & 50 & 0.946 \\
\hline
\end{tabular}


Table 3. Relationship between the electrical current and the average distance between the screws and the medial cortical of the pedicle.

\begin{tabular}{c|c|c}
\hline Electrical Current & $\begin{array}{c}\text { Number of } \\
\text { screws }\end{array}$ & $\begin{array}{c}\text { Average distance from } \\
\text { the screws to the unit of } \\
\text { measurement }\end{array}$ \\
\hline Less than $24.4 \mathrm{~mA}$ & 10 & 3.68 \\
\hline Between $24.4 \mathrm{~mA}$ and $30.2 \mathrm{~mA}$ & 10 & 2.67 \\
\hline Between $30.2 \mathrm{~mA}$ and $36.2 \mathrm{~mA}$ & 10 & 3.41 \\
\hline Between $36.2 \mathrm{~mA}$ and $46.2 \mathrm{~mA}$ & 10 & 3.82 \\
\hline Greater than $46.2 \mathrm{~mA}$ & 10 & 4.23
\end{tabular}

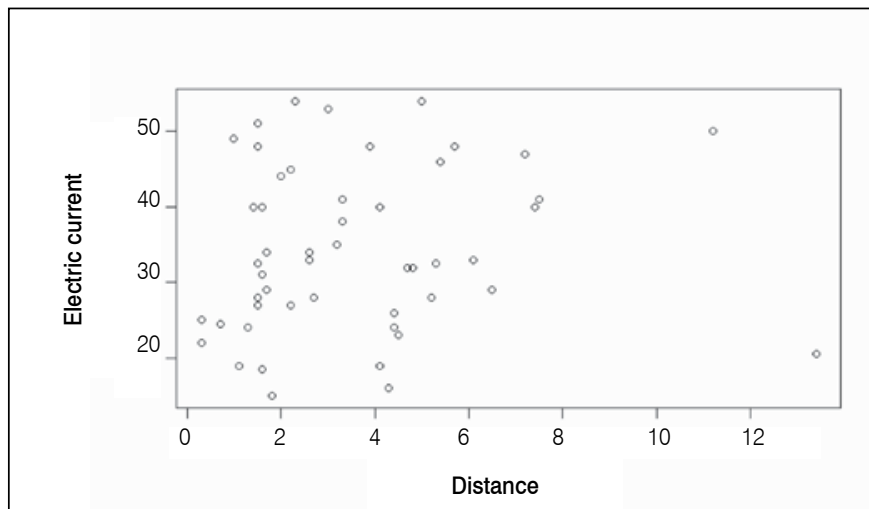

Figure 1. Dispersion showing electrical current and the distance of each instrumented screw.

the propagation of lumbosacral arthrodesis via a strictly posterior approach arthrodesis technique using pedicle screws. Thus emerged the idea of studying the safety of placing pedicular screws by means of electroneurophysiological stimulation, as well as to observe whether a correlation exists between the transoperative impedance values and the distance between the screw and the pedicular cortical wall.

In the current literature, a medial cortical extravasation of the pedicle of up to $2 \mathrm{~mm}$ following screw instrumentation is considered to be safe in most cases. ${ }^{6}$ According to Gertzbein and Robbins, ${ }^{21}$ there is zone of up to $4 \mathrm{~mm}$ considered to be safe in the medial portion of the pedicle, corresponding to $2 \mathrm{~mm}$ of epidural space and $2 \mathrm{~mm}$ of subarachnoid space.

According to the values shown in Table 3, there was no violation of the medial cortical of the pedicle, viewed postoperatively by computed tomography, given that the mean distance of the screws to the medial cortical was greater than $2 \mathrm{~mm}$.

The pedicle screw instrumentation technique depends on great precision, ${ }^{1}$ and thus relies on a broad knowledge of anatomy as well as experience, which is independent of the position of the surgeon during the operation. There was no significant difference between the average electrical current of the screws instrumented by the surgeons in terms of their positions, since both used the surgical technique in a precise and accurate manner according to the information described in the literature by Lenke.22 This was evidenced by the by the t test in combination with the Levene test, which were used to test the equality between the variances and to verify which test should be used. The p-value was not significant (0.624), indicating that the variances are equal, so the t test can consider such an equality, in which the $p$-value of the test for equal variances was not significant at $5 \%(p=0.2841)$, as shown in Table 1.

The results showed that there was no significant difference in the distance from the screws to the pedicle cortical wall as viewed via computed tomography in the immediate postoperative period in terms of the position of the surgeons. The Wilcoxon test, which is the non-parametric equivalent of the test, was required to analyze this relationship, in which the $p$-value of the test was not significant at $5 \%(p=0.946)$, as shown in Table 2 , indicating that there was no evidence of a difference between the average distance of the screws placed by the surgeons according to their positions.

Lenke et al. ${ }^{22}$ associated impedance values greater than $8 \mathrm{~mA}$ in instrumented pedicle screws in the lumbar segment with proper positioning. Values between 4.0 and $8.0 \mathrm{~mA}$ suggested a probable rupture in the medial wall and finally values less than 4.0mA suggested a transposition to the medial wall of the pedicle. According to the results, the lowest value of the electrical current measured transoperatively was $10 \mathrm{~mA}$, which was associated with the integrity of the medial wall of the pedicle, and that would confirm Lenke's interpretation.

In a recent review of the literature, we did not identify any study since 2007 where there was a report of malpositioning of pedicular screws associated with neurostimulation in terms of the direct association between the variables of electrical current and the distance of the screw, ${ }^{23}$ which persisted in the data collected as it appears in the dispersion in Figure 1 and in the spectrum of values observed in the sample according to Table 3, where the average distance of the screws is categorized by quintiles for the variable electrical current. It can be seen that an increase in the electrical current does not modify the distance of the screws significantly, however the average distances of the screws in the selected sample were all greater than $2 \mathrm{~mm}$, which proves the non-violation of the medial cortical wall of the pedicle, associated with the lowest value of the electrical current being greater than $10 \mathrm{~mA}$, which confirms the hypothesis of a quantitative method to evaluate the pedicular integrity in our sample of 50 pedicle screws.

\section{CONCLUSION}

There was no interval of impedance values measured transoperatively that were significantly associated with the values of the distance between the pedicle screw and the medial cortical wall of the pedicle as measured in immediate postoperative computed tomography. However, the electroneurostimulation method was shown to be a safe quantitative method for reducing the risk of intraoperative nerve root lesions in lumbar spine arthrodesis when the values measured are greater than $10 \mathrm{~mA}$, given that there was no observed violation of the pedicle screws path in our study.

\section{ACKNOWLEDGEMENTS}

We thank Taciana Arruda M. Sugai and Rosimara E. F. Almeida Camêlo for their contributions to the realization of this study.

All the authors declare that there are no conflicts of interest regarding this article.

CONTRIBUTIONS OF THE AUTHORS: Each author made significant individual contributions to the development of this manuscript. LFF, LMP, and IABN were the main contributors to the writing of the manuscript. LAF, EGF, LFF, and RS performed the surgeries, monitored the patients, and collected the clinical data. IABN and LMP evaluated the statistical analysis data. LFF, IABN, LAF, and EGF conducted the bibliographical research. LFF and RS were responsible for the review of the manuscript. All the collaborators contributed to the intellectual concept of the study.

\section{REFERENCES}

1. Galindo $\mathrm{MH}$, Galindo $\mathrm{RH}$, Medeiros RC, Pereira AF, Ferreira MA, Rangel TM. Parafusos pediculares mal posicionados pela técnica freehand: qual o real valor para o surgimento de lesões neurológicas? Coluna/Columna. 2013;12(4):315-8.
2. Avanzi $O$, Chih $L Y$, Meves R. Avaliação do tratamento cirúrgico da fratura toracolombar com material de terceira geração. Rev Bras Ortop. 2002;37(6):226-32.

3. Cotrel Y, Dubousset J. A new technic for segmental spinal osteosynthesis using the 
posterior approach. Rev Chir Orthop Reparatrice Appar Mot. 1984;70(6):489-94

4. Cotrel Y, Dubousset J, Guillaumat M. New universal instrumentation in spinal surgery Clin Orthop Relat Res. 1988:(227):10-23.

5. Kim YJ, Lenke LG, Bridwell KH, Cho YS, Riew KD. Free hand pedicle screw placement in the thoracic spine: is it safe? Spine (Phila Pa 1976). 2004;29(3):333-42.

6. Ravi B, Zahrai A, Rampersaud R. Clinical accuracy of computer-assisted two-dimensiona fluoroscopy for the percutaneous placement of lumbosacral pedicle screws. Spine (Phila Pa 1976). 2011;36(1):84-91.

7. Belmont PJ Jr, Klemme WR, Dhawan A, Polly DW Jr. In vivo accuracy of thoracic pedicle screws. Spine (Phila Pa 1976). 2001;26(21):2340-6.

8. Ferrick MR, Kowalski JM, Simmons ED Jr. Reliability of roentgenogram evaluation of pedicle screw position. Spine (Phila Pa 1976). 1997;22(11):1249-52.

9. Kalfas IH, Kormos DW, Murphy MA, McKenzie RL, Barnett GH, Bell GR, et al. Application of frameless stereotaxy to pedicle screw fixation of the spine. J Neurosurg. 1998;83(4):641-7.

10. Odgers CJ 4th, Vaccaro AR, Pollack ME, Cotler JM. Accuracy of pedicle screw placement with the assistance of lateral plain radiography. J Spinal Disord. 1996:9(4):334-8.

11. Xu R, Ebraheim NA, Shepherd ME, Yeasting RA. Thoracic pedicle screw placement guided by computed tomographic measurements. J Spinal Disord. 1999;12(3):222-6.

12. Berlemann U, Heini P, Müller U, Stoupis C, Schwarzenbach O. Reliability of pedicle screw assessment utilizing plain radiographs versus CT reconstruction. Eur Spine J. 1997:6(6):406-10.

13. Vaccaro AR, Rizzolo SJ, Allardyce TJ, Ramsey M, Salvo J, Balderston RA, et al. Placement of pedicle screws in the thoracic spine. Part I: Morphometric analysis of the thoracic vertebrae. J Bone Joint Surg Am. 1995;77(8):1193-9.

14. Farber GL, Place HM, Mazur RA, Jones DE, Damiano TR. Accuracy of pedicle screw placement in lumbar fusions by plain radiographs and computed tomography. Spine
(Phila Pa 1976). 1995;20(13):1494-9

15. Calancie B, Lebwohl N, Madsen P, Klose KJ. Intraoperative evoked EMG monitoring in an animal model. A new technique for evaluating pedicle screw placement. Spine (Phila Pa 1976). 1992;17(10):1229-35.

16. Raynor BL, Lenke LG, Kim Y, Hanson DS, Wilson-Holden TJ, Bridwell KH, Padberg AM. Can triggered electromyograph thresholds predict safe thoracic pedicle screw placement? Spine (Phila Pa 1976). 2002;27(18):2030-5.

17. Li G, Lv G, Passias P, Kozanek M, Metkar US, Liu Z, Wood KB, et al. Complications associated with thoracic pedicle screws in spinal deformity. Eur Spine J. 2010;19(9):1576-84.

18. Freeman BL. Escoliose e cifose. In: Canale ST. Cirurgia ortopédica de Campbell. $10^{\mathrm{a}} \mathrm{ed}$ São Paulo: Manole; 2006. p. 1751-954

19. Polly DW Jr, Potter BK, KukloT, Young S, Johnson C, Klemme WR. Volumetric spinal canal intrusion: a comparison between thoracic pedicle screws and thoracic hooks. Spine (Phila Pa 1976). 2004:29(1):63-9.

20. Kim YB, Lenke LG, Kim YJ, Kim YW, Blanke K, Stobbs G, et al. The morbidity of an anterior thoracolumbar approach: adult spinal deformity patients with greater than five-year follow-up. Spine (Phila Pa 1976). 2009;34(8):822-6.

21. Gertzbein SD, Robbins SE. Accuracy of pedicular screw placement in vivo. Spine (Phila Pa 1976). 1990;15(1):11-4

22. Lenke LG, Padberg AM, Russo MH, Bridwell KH, Gelb DE. Triggered electromyographic threshold for accuracy of pedicle screw placement. An animal model and clinical correlation. Spine (Phila Pa 1976). 1995;20(14):1585-91.

23. Raynor BL, Lenke LG, Bridwell KH, Taylor BA, Padberg AM. Correlation between low triggered electromyographic thresholds and lumbar pedicle screw malposition: analysis of 4857 screws. Spine (Phila Pa 1976). 2007;32(24):2673-8. 